\title{
Soil fungal community in eucalyptus cultivation cycles
}

\author{
Julio Cesar Delvaux ${ }^{1 *} \oplus$, Paulo Sérgio Balbino Miguel ${ }^{2}$, Marcelo Nagem Valério de Oliveira ${ }^{3} \oplus$, \\ Reginaldo de Camargo ${ }^{4}\left({ }^{\circ}\right.$, Rafael Arcanjo Gonçalves ${ }^{1} \oplus$, Miguel Henrique Rosa Franco ${ }^{4}$

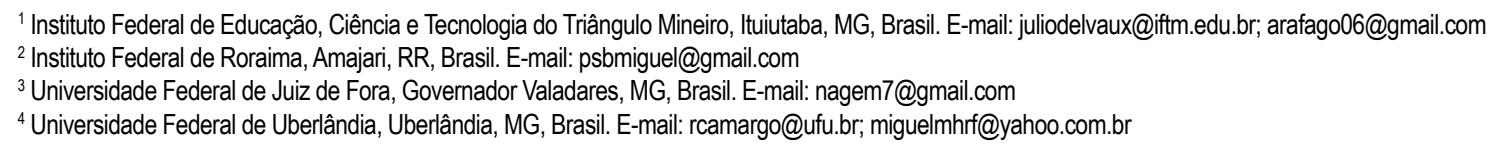

ABSTRACT: The short production cycle, high biomass production, and adaptability to various edofoclimatic conditions have led the eucalyptus to a prominent position in the world forestry sector. However, little is known about fungal community structure in these crops. This work aimed to evaluate the structure of soil fungal communities in eucalyptus forests as a function of rhizosphere effect and crop cycles of this crop. We used the independent PCR-DGGE method to evaluate the structure of the soil fungal community in Eucalyptus urograndis plantations located in the Vale do Rio Doce region, Minas Gerais, Brazil. The rhizospheric and non-rhizospheric portions of the soil were sampled in an area of recent forest establishment and in an area under multiple cycles. The principal component analysis revealed that the rhizosphere microenvironment is the dominant component in structuring the fungal communities in the areas studied, and this effect is more pronounced in the area of recent establishment of eucalyptus culture. The same pattern was found for the richness and diversity values, with the greatest differences found in the recently established area. In both studied areas the dominance of the order Agaricales prevailed, evidencing the role of the fungal community in the cycling of nutrients in the soil.

Key words: priming effect; PCR-DGGE; rhizosphere

\section{Comunidade fúngica do solo em ciclos de cultivo do eucalipto}

RESUMO: O curto ciclo de produção, a elevada produção de biomassa ea adaptabilidade às diversas condições edofoclimáticas levaram o eucalipto à posição de destaque no setor mundial de florestas. Contudo, pouco se conhece sobre estrutura da comunidade fúngica nestes cultivos. Este trabalho teve como objetivo avaliar a estrutura das comunidades fúngicas do solo em florestas de eucalipto em função do efeito rizosférico e dos ciclos de cultivo desta cultura. Utilizou-se o método independente de PCR-DGGE para avaliação da estrutura da comunidade fúngica do solo em cultivos de Eucalyptus urograndis localizadas na região do Vale do Rio Doce, Minas Gerais, Brasil. Foram amostradas as porções rizosférica e não-rizosférica do solo em área de recente implantação da floresta e em área sob múltiplos ciclos. A análise de componentes principais revelou que o microambiente rizosférico é o componente dominante na estruturação das comunidades fúngicas nas áreas estudadas, sendo este efeito mais pronunciado na área de recente implantação da cultura do eucalipto. 0 mesmo padrão foi encontrado para os valores de riqueza e diversidade, sendo as maiores diferenças encontradas na área de recente implantação. Em ambas as áreas estudadas prevaleceu a dominância da ordem Agaricales, evidenciando o papel da comunidade fúngica na ciclagem de nutrientes no solo.

Palavras-chave: efeito priming; PCR-DGGE; rizosfera

\footnotetext{
* Julio Cesar Delvaux - E-mail: juliodelvaux@iftm.edu.br (Corresponding author)

Associate Editor: Mário de Andrade Lira Júnior
} 


\section{Introduction}

Eucalyptus is the most planted industrial wood species in the tropics, covering 20 million hectares, and is exploited mainly for the excellent properties of its pulp and for its short production cycle and adaptability to various soil and climate conditions (FAO, 2020).

In forest crops, trees contribute large amounts of carbon to the soil in the form of residues and root exudates, and root exudation is one of the main determinants of microbial activity in the rhizosphere (Andresen et al., 2020).

The rhizospheric environment provides the microbiota of this habitat with two faces, the first facing the root, full of readily available carbon compounds, and the other facing the soil, an often oligotrophic environment where survival requires great metabolic plasticity (Omotayo \& Babalola, 2020). The rhizospheric habitat hosts a large network of microorganisms, mostly sustained and driven by the high input of organic carbon from root exudation (Lance et al., 2020).

It is known that the formation of specific communities associated with the rhizosphere of plant species is determined by complex gene interactions (Gong et al., 2019) and that the molecular approach has contributed to the better understanding of these interactions (Braga et al., 2016). Fingerprinting techniques such as Denaturing Gradient Gel Electrophoresis (DGGE) are able to provide short-term and cost-effective data on the genetic diversity of a specific environment as well as provide comparisons between different environments (Green et al., 2015).

Colonization and permanence in rhizospheric habitat seems to require more than simple craving for energy, being determined primarily by complex gene interactions between plants and rhizospheric microorganisms (Trivedi et al., 2020).

Most of the plants studied on the planet have successful interactions with a wide variety of microorganisms, many of them colonizing the rhizosphere. In this complex habitat, fungi play essential roles, either as mutualistic decomposers or pathogens (Mommer et al., 2018).

Fungi are heterotrophic organisms dependent on external sources of reduced carbon (Marupakula et al., 2020). Studies on the contribution of root exudates of Fagus sylvatica $L$. to the soil reveal the ability of photoassimilates to shape the fungal community of this habitat (Baumert et al., 2018).

Microbial diversity is seen as a critical factor for soil quality (Schloter et al., 2018). Despite the existence of several papers evidencing the induction of plant species on pathogenic and mycorrhizal fungal communities, few papers report the rhizosphere effect on non-symbiont fungal communities in the soil.

Considering the importance of plant-micro-organism interactions in the rhizosphere for soil carbon retention, nutrient cycling, and the sustainability of forest systems, understanding the factors that determine the structure of fungal communities in these ecosystems is critical. Thus, the present work aimed to evaluate the structure of soil fungal communities in eucalyptus forests as a function of crop cycles and rhizospheric effect in Eucalyptus urograndis located in the Vale do Rio Doce region, Minas Gerais, Brazil.

\section{Materials and Methods}

\section{Area description}

To conduct the experiments, areas cultivated with Eucalyptus urograndis were selected and located in the Vale do Rio Doce region, Minas Gerais, Brazil. Two plots were selected in areas with different crop cycles, the first fifth cycle (Area 1) and the second in the first cycle (Area 2), both containing 18-month old trees. In the experimental areas there is a predominance of intemperate soils, with low natural fertility and with an undulating relief, from wavy to strongly undulated, being the yellow Latosol the most representative soil class (Table 1). The average annual temperature is $22.2^{\circ} \mathrm{C}$ and the average annual precipitation $1212 \mathrm{~mm}$.

\section{Soil sampling}

The $1000 \mathrm{~g}$ soil samples from the $0-10 \mathrm{~cm}$ layer were collected from the rhizospheric and non-rhizospheric region of each of the areas. For the rhizospheric soil, the average collection radius was set so as to intercept the growth zone of fine roots near the soil surface. For this study, the rhizospheric portion was considered to be the entire volume of soil in contact with the root system of the eucalyptus plants. Nonriphospheric soil was collected in the center of the planting rows in a region where root growth was not observed.

\section{Extraction of metagenomic DNA, PCR-DGGE and identification of UTOs of interest}

For DNA extraction from soil fungal populations, the PowerSoil ${ }^{\circledR}$ DNA Isolation Kit (MoBio Laboratories Inc., Carlsbad, CA, USA) was used with modifications. Twenty-five $\mathrm{mg}$ of each soil sample was transferred into PowerBead tubes provided by the kit followed by incubation in a water bath at $55^{\circ} \mathrm{C}$ for 30 minutes. After cooling to room temperature, the sample was processed using the kit according to the manufacturer's recommendation.

Table 1. Chemical and physical characteristics of the soils of areas and stands of Eucalyptus urograndis located in the Vale do Rio Doce region, Minas Gerais, Brazil, with different crop cycles, the first fifth cycle (Area 1) and the second in the first cycle (Area 2), both containing 18-month-old trees.

\begin{tabular}{|c|c|c|c|c|c|c|c|c|c|}
\hline \multirow{2}{*}{ Project } & $\mathrm{pH}$ & $\mathbf{P}$ & K & $\mathrm{Ca}^{2+}$ & $\mathrm{Mg}^{2+}$ & $\mathrm{Al}^{3+}$ & \multirow{2}{*}{$\begin{array}{c}O M \\
\left(\operatorname{dag~kg}^{-1}\right)\end{array}$} & \multirow{2}{*}{$\begin{array}{l}\text { Prem } \\
\left(\mathrm{mg} \mathrm{L}^{-1}\right)\end{array}$} & \multirow{2}{*}{$\begin{array}{c}\mathbf{N} \\
\left(\text { dag kg }^{-1}\right)\end{array}$} \\
\hline & $\mathrm{H}_{2} \mathrm{O}$ & \multicolumn{2}{|c|}{$\left(\mathrm{mg} \mathrm{dm}^{-3}\right)$} & \multicolumn{3}{|c|}{$\left(\mathrm{cmol}_{\mathrm{c}} \mathrm{dm}^{-3}\right)$} & & & \\
\hline Area 1 & 4.5 & 1.50 & 24 & 0.05 & 0.06 & 1.75 & 3.55 & 15.2 & 0.126 \\
\hline Area 2 & 4.4 & 0.65 & 16 & 0.05 & 0.06 & 1.90 & 5.32 & 12.1 & 0.129 \\
\hline
\end{tabular}


Table 2. Primers and PCR conditions.

\begin{tabular}{|c|c|c|c|c|}
\hline Primer & Sequence $\left(5^{\prime} \rightarrow 3^{\prime}\right)$ & Fragment & $\begin{array}{c}\text { Amplification } \\
\text { conditions } \\
\end{array}$ & Reference \\
\hline & & & $94^{\circ} \mathrm{C} 4 \mathrm{~min}$ & \\
\hline NS1 & GTAGTCATATGCTTGTCTC & & $(35 x)$ & May et al. (2001) \\
\hline EF3 & TCCTCTAAATGACCAAGTTTG & $1800 \mathrm{bp}$ & $\begin{array}{c}94^{\circ} \mathrm{C} 1 \mathrm{~min} \\
47^{\circ} \mathrm{C} 1 \mathrm{~min} \\
72^{\circ} \mathrm{C} 2 \mathrm{~min} \\
--- \\
72^{\circ} \mathrm{C} 10 \mathrm{~min}\end{array}$ & $\begin{array}{l}\text { Oros-Sichler et al. } \\
\qquad(2006)\end{array}$ \\
\hline FR1GC & AICCATTCAATCGGTAIT & 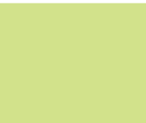 & $\begin{array}{c}94{ }^{\circ} \mathrm{C} 4 \mathrm{~min} \\
-- \\
(35 x)\end{array}$ & \\
\hline FF390 & 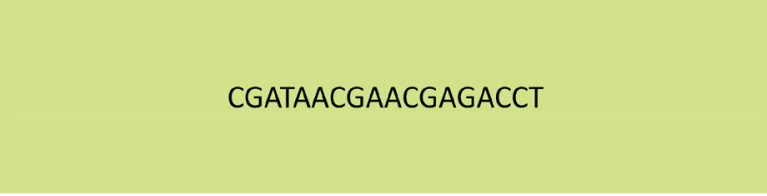 & $350 \mathrm{bp}$ & $\begin{array}{c}94^{\circ} \mathrm{C} 1 \mathrm{~min} \\
50^{\circ} \mathrm{C} 1 \mathrm{~min} \\
72{ }^{\circ} \mathrm{C} 2 \mathrm{~min} \\
--- \\
72{ }^{\circ} \mathrm{C} 10 \mathrm{~min}\end{array}$ & Vainio \& Hantula (2000) \\
\hline GC Clamp & CGCCCGGGGCGCGCCCCGGGCGGGGCGGGGGCACGGGGGG & & & Nübel et al. (1996) \\
\hline
\end{tabular}

The DNA obtained was used to amplify a fragment spanning the V1-V9 regions of the 18S rDNA (May et al., 2001; Oros-Sichler et al., 2006) and the products of the first PCR used as a template to amplify a fragment between the V7-V8 regions (Vainio \& Hantula, 2000) (Table 2).

The separation of the different amplicons was performed by applying $20 \mu \mathrm{L}$ of the PCR product in Denaturing Gradient Gel Electrophoresis (DGGE) with 35\% to 55\% urea/formamide gradient and electrophoresis conducted at a temperature of $60{ }^{\circ} \mathrm{C}$, constant voltage of $60 \mathrm{~V}$ for 20 hours in DCodeTM Universal Mutation Detection System equipment (BIO-RAD-, CA, USA), following the manufacturer's recommendations. The gel was stained with SYBR ${ }^{\circledR}$ Gold (Invitrogen, Carlsbad, CA, USA).

\section{Identification of the UTOs}

After visual analysis of the DGGE gel the bands corresponding to the most representative OTUs from the rhizospheric and non-rhizospheric soils were excised from the gel and eluted in $30 \mu \mathrm{L}$ of sterile water. The elution product was used as a template for further amplification of the region of interest (Table 2). The amplicons obtained by PCR were sent for sequencing at Macrogen Inc., Korea.

\section{Statistical analysis}

Fungal community structure analysis was based on Dice's similarity coefficient and the UPGMA method (Unweighted Pair Group Method with Arithmetic) to build the clusters, using Bionumerics software, version 7.1 (Applied Maths, Kortrijk, Belgium). Richness (R) and Shannon diversity $(H)$ indices were calculated using Paleontological Statistics (PAST) software from the presence and absence matrices generated from the analysis of the DGGE profiles. The data from the richness and diversity analyses were evaluated with the help of ASSISTAT Version 7.7.

\section{Results}

\section{Fungal community structure}

Principal component analysis (PCA) showed the formation of distinct groups between the fungal communities of rhizospheric and non-rhizospheric soils, revealing that the input of carbon compounds into the rhizosphere is the dominant component in structuring fungal communities in eucalyptus forest soils (Figure 1).

A higher similarity was observed between the clusters formed by the rhizospheric and non-rhizospheric soil samples collected in the area under the first cycle (A2), about $60 \%$ similarity, when compared to the rhizospheric and nonrhizospheric soil clusters collected in the area under multiple cycles (Area 1), about $43 \%$ similarity (Figure 2).

Significant differences in richness $(R)$ and diversity $(H)$ values were observed between the rhizospheric and nonrhizospheric soils in the recent crop establishment area (A2), with the rhizospheric soil showing higher $R$ and $H$ values. Similar $\mathrm{R}$ and $\mathrm{H}$ values were found between rhizospheric and

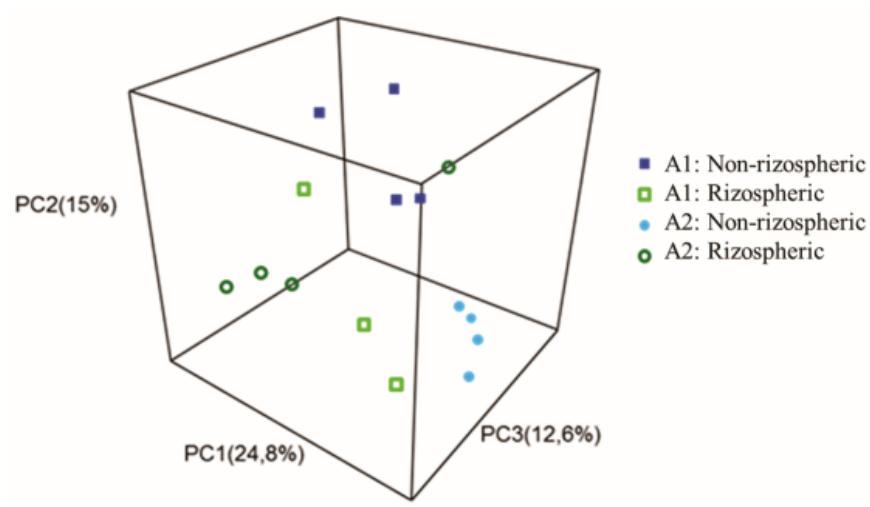

Figure 1. Principal component analysis (PCA) of fungal communities in rhizospheric and non-rhizospheric soils of Eucalyptus urograndis forests. The ordering considered the presence and absence of fungal 18S rDNA amplicons. 


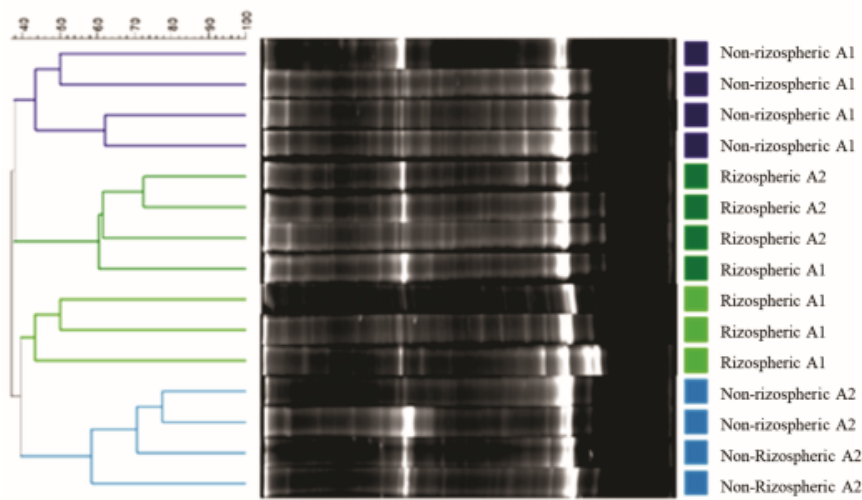

Figure 2. DGGE electrophoretic profiles of rDNA fragments detected based on the separation of 18S rDNA amplicons from fungal communities present in rhizospheric and nonrhizospheric soils of Eucalyptus urograndis planted forests in areas under multiple cropping cycles (A1- fifth cropping cycle) and of recent establishment, first cycle (A2- first cropping cycle).

non-rhizospheric soils collected in the area under multiple crop cycles (A1) (Table 3).

The migration pattern of DNA fragments in DGGE revealed distinct UTOs of fungi in the analyzed soils (Figure 3 ), of which only four are present in all sampled soils. Six UTOs were found to be unique to rhizospheric soil, while only three are present only in non-rhizospheric soil. The rhizospheric soil from the area under multiple crop cycles (A1) showed four distinct OTUs, the rhizospheric soil from area 2, one OTU, and the non-rhizospheric soils, from areas 1 and 2, only one distinct OTU (Figure 4).

Identification of the bands eluted from the DGGE gel (Figure 3) revealed the presence of 14 genera present in rhizospheric and non-rhizospheric soils (Table 6): Volvopluteus, Volvariella, Descolea, Serpula, Phellinus, Cerrena, Pleurotus, Pleuroflammula, Hypsizygus, Paragyrodon, Entoloma, Gomphus, Hydnangium, and Spiromyces; seven of these belong to the order Agaricales (Figure 5). Among the identified UTOs only two, Serpula and Pleuroflammula were present only in the rhizospheric soil.

\section{Discussion}

Principal component and cluster analysis obtained from the PCR-DGGE data reveals the differences between the fungal

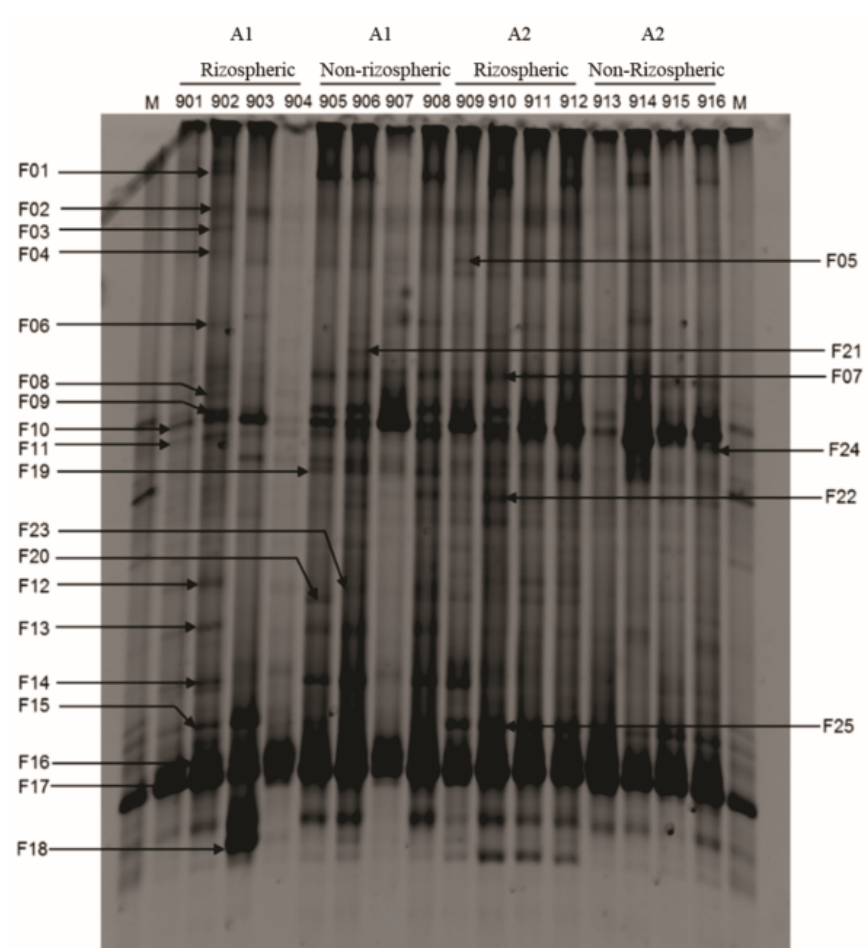

Figure 3. DGGE of the $18 \mathrm{~S}$ rDNA sequences of fungi amplified from rhizospheric and non-rhizospheric soil samples from Eucalyptus urograndis forests at different crop cycles. The channel numbers correspond to the number of samples along the different areas. The labeled bands were excised from the SYBR Gold stained gel and sequenced. The arrows indicate the positions of each band quoted throughout the work.

communities in the rhizospheric soil and the non-rhizospheric soil in both areas studied. This observation confirms the hypothesis that the high input of carbon compounds from the aerial part into the rhizosphere is able to shape the structure of the fungal community in this habitat.

There is much evidence to support the hypothesis that the supply of carbon through root exudation is a major determinant of soil microbial community structure. In Cunninghamia lanceolata forest (He et al., 2016) in China, the disruption of carbon flux to the rhizospheric environment by tree girdling was found to be a major component determining soil microbial community structure. Also in China, tree ringing in Pinus elliottii forests has considerably altered the soil microbial community structure (Wan et al., 2019).

Diversity and community structure data obtained by PCRDGGE have to be analyzed with caution, as heterogeneity

Table 3. Average richness (R) and Shannon diversity $(H)$ values of fungal OTUs in rhizospheric and non-rhizospheric soil in a Eucalyptus urograndis forest in the Vale do Rio Doce region, Minas Gerais, Brazil.

\begin{tabular}{cccc}
\hline & Average richness and diversity values of the soil fungi OTUs & \\
\hline Area & Soil & Richness (R) & Diversity (H) \\
\hline \multirow{2}{*}{ A1: Multiple cycles } & Rhizospheric & $19.00 \mathrm{ab}$ & $2.95 \mathrm{~A}$ \\
& Non-rhizospheric & $19.75 \mathrm{a}$ & $2.98 \mathrm{~A}$ \\
\multirow{2}{*}{ A2: First cycle } & Rhizospheric & $17.5 \mathrm{~b}$ & $2.86 \mathrm{~B}$ \\
& Non-rhizospheric & $14.75 \mathrm{C}$ & $2.69 \mathrm{C}$ \\
\hline
\end{tabular}

${ }^{1 /}$ Richness (R) and Shannon Diversity $(\mathrm{H})$ values. Averages of richness values followed by the same lower case letter and of diversity by the same upper case letter do not differ by Tukey test at $5 \%$. 


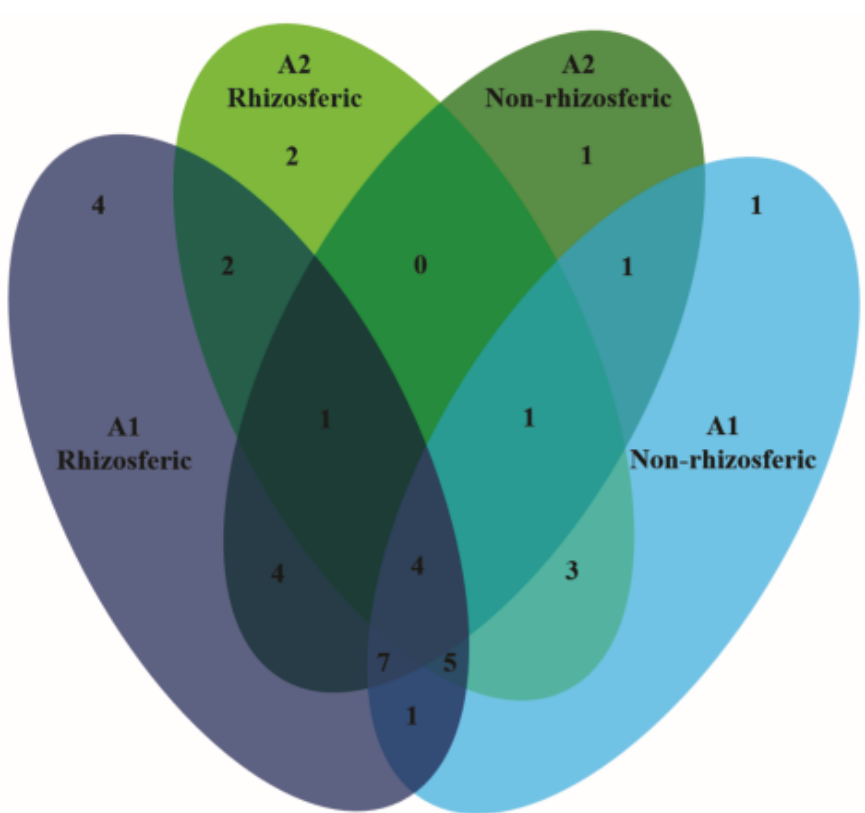

Figure 4. Comparison of the number of fungal OTUs, identified by DGGE, found in rhizospheric and non-rhizospheric soils in Eucalyptus urograndis forests at different cropping cycles; $A 1$ : multiple cropping cycles and A2: first cropping cycle.

Table 4. Closest species obtained from comparison of sequences obtained from bands excised from the DGGE gel and sequences from the GenBank/EMBL/DDBJ database.

\begin{tabular}{llllc}
\hline Band & \multicolumn{1}{c}{ Closest genre in BLAST } & $\begin{array}{c}\text { Access } \\
\text { number }\end{array}$ & E-value & Similarity \\
\hline F01 & Volvopluteus [HM562270.1] & KP090348 & $1 \mathrm{e}^{-140}$ & $97 \%$ \\
F02 & Volvariella [DQ089020.1] & KP090349 & $1 \mathrm{e}^{-115}$ & $99 \%$ \\
\hline F03 & Descolea [KJ137258.1] & KP090350 & $8 \mathrm{e}^{-117}$ & $99 \%$ \\
\hline F04 & Volvopluteus [HM562270.1] & KP090351 & $5 \mathrm{e}^{-145}$ & $99 \%$ \\
\hline F05 & Serpula [GU187654.1] & KP090352 & $2 \mathrm{e}^{-138}$ & $98 \%$ \\
F06 & Descolea [KJ137258.1] & KP090353 & $4 \mathrm{e}^{-131}$ & $95 \%$ \\
\hline F07 & Volvariella [DQ089020.1] & KP090354 & $1 \mathrm{e}^{-91}$ & $90 \%$ \\
\hline F08 & Volvopluteus [HM562270.1] & KP090355 & $5 \mathrm{e}^{-135}$ & $97 \%$ \\
\hline F09 & Phellinus [AY178022.1] & KP090356 & $5 \mathrm{e}^{-135}$ & $98 \%$ \\
\hline F10 & Cerrena [GQ899199.1] & KP090357 & $3 \mathrm{e}^{-137}$ & $97 \%$ \\
\hline F11 & Pleurotus [FJ379285.1] & KP090358 & $1 \mathrm{e}^{-130}$ & $98 \%$ \\
F12 & Pleuroflammula [KJ137265.1] & KP090359 & $2 \mathrm{e}^{-114}$ & $93 \%$ \\
\hline F13 & Hypsizygus [KF150213.1] & KP090360 & $2 \mathrm{e}^{-93}$ & $94 \%$ \\
\hline F14 & Paragyrodon [GU187642.1] & KP090361 & $1 \mathrm{e}^{-110}$ & $98 \%$ \\
\hline F15 & Paragyrodon [GU187642.1] & KP090362 & $1 \mathrm{e}^{-110}$ & $98 \%$ \\
F16 & Entoloma [NG_013174.1] & KP090363 & $5 \mathrm{e}^{-109}$ & $98 \%$ \\
\hline F17 & Entoloma [NG_013174.1] & KP090364 & $2 \mathrm{e}^{-92}$ & $100 \%$ \\
\hline F18 & Gomphus [AY752968.1] & KP090365 & $1 \mathrm{e}^{-131}$ & $95 \%$ \\
\hline F19 & Hydnangium [HQ832423.1] & KP090366 & $6 \mathrm{e}^{-149}$ & $98 \%$ \\
F20 & Hydnangium [HQ832423.1] & KP090367 & $9 \mathrm{e}^{-143}$ & $97 \%$ \\
\hline F21 & Hydnangium [HQ832423.1] & KP090368 & $4 \mathrm{e}^{-151}$ & $98 \%$ \\
\hline F22 & Hydnangium [HQ832423.1] & KP090369 & $1 \mathrm{e}^{-145}$ & $98 \%$ \\
F23 & Hydnangium [HQ832423.1] & KP090370 & $3 \mathrm{e}^{-142}$ & $98 \%$ \\
F24 & Spiromyces [AF007542.1] & KP090371 & $2 \mathrm{e}^{-119}$ & $91 \%$ \\
\hline F25 & Hydnangium [HQ832423.1] & KP090372 & $4 \mathrm{e}^{-151}$ & $99 \%$ \\
\hline & & & \\
\hline
\end{tabular}

within the analyzed regions or the occurrence of PCRpreferential may overestimate the diversity of a species or underestimate the diversity of infrequently present species (lacumin et al., 2020). Popularly known as rare biosphere,

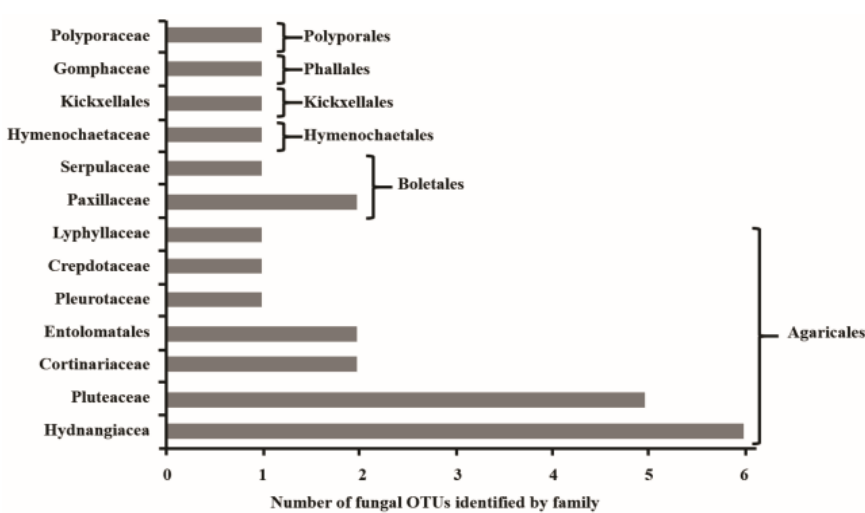

Figure 5. Number of fungal OTUs identified by family in rhizospheric and non-rhizospheric soils of Eucalyptus urograndis forests in areas under multiple cropping cycles (A1- fifth cropping cycle) and recent establishment, first cycle (A2- first cropping cycle).

these species are individually present in small numbers, but can account for $75 \%$ of the biomass of some microbial communities (Zhang et al., 2019).

The smaller distinction between the clusters formed by the rhizospheric communities in the area under multiple cropping cycles when compared to those formed in the first-cycle areas shows that the rhizospheric effect is more pronounced when forests are planted. It turns out that successive crops in monoculture are capable of shaping the structure of the entire soil fungal community, whether rhizospheric or non-rhizospheric.

Studies conducted in forest soils highlight that the introduction of new plant species is able to significantly alter the structure and activity of the soil microbial community (Arafat et al., 2019). There is evidence that anthropogenic restructuring of microbial communities is mediated by changes in the quality and quantity of carbon input to the soil (Domeignoz-Horta et al., 2020).

The similarity between the richness and diversity values of rhizospheric and non-rhizospheric soils in areas under multiple cycles of $E$. urograndis cultivation reaffirms the hypothesis that monoculture is able to shape and stabilize the soil microbial community.

When these parameters, richness and diversity, are analyzed in areas of recent crop establishment, a more pronounced rhizospheric effect is observed, which considerably increases the richness and diversity values. We infer this result to the priming effect leveraged by the addition of carbon to the rhizospheric environment in a region previously degraded by pasture. In E. uroplylla crops in southern China, forest monoculture was found to lead to increased fungal diversity in the soil, with the result being attributed to the possible favoring of these communities by stabilizing the chemical composition of the rhizosphere environment (Zhu et al., 2020).

It is proposed that the priming effect does not involve just one mechanism, but is the result of a complex interplay of sequential mechanisms directly linked to the structure of soil microbial communities (Li et al., 2018). 
Most of the identified OTUs belong to the order Agaricales, which highlights the role of the fungal community in organic matter mineralization and nutrient availability in eucalyptus forests. The order Agaricales is the most diverse of the phylum Basidiomycota, comprising about 9387 species in 347 genera. Representatives of this order are recognized as critical components in organic matter cycling and for their high potential for producing antimicrobial metabolites (Kyaschenko et al., 2017).

On forest sites the soil fungal community plays an essential role in the carbon, phosphorus and nitrogen cycles, acting, primarily through enzymatic mechanisms, in making these nutrients available and enabling the establishment of other microbial populations (Shi et al., 2019). In Eucalyptus grandis forests in Ethiopia it was found that fungal community structure is directly correlated to the presence of roots (Castaño et al., 2019).

\section{Conclusions}

There was the formation of distinct groups between the fungal communities in rhizospheric and non-rhizospheric soils, demonstrating that the rhizospheric effect contributes expressively to determining the structure of the communities in E. urograndis forest soils. Verificou-se ainda que, em menor escala, o cultivo sucessivo contribui para moldar a estrutura destas comunidades.

The lowest similarity between the fungal communities in the rhizospheric and non-rhizospheric soils was seen in the area under multiple cultivation when compared to the first cycle area, showing that the rhizospheric effect is more pronounced at forest planting. The same pattern was found for the richness and diversity values, with the greatest differences found in the recently established area.

Among identified fungal OTUs, mostly belonging to the order Agaricales, most were present in rhizospheric and nonrhizospheric soils, except for Serpula and Pleuroflammula OTUs, which were present only in rhizospheric soil.

\section{Compliance with Ethical Standards}

Author contributions: Conceptualization: JCD, PSBM, MNVO; Data curation: JCD, PSBM, MNVO, RC, RAG, MHRF; Formal analysis: JCD, PSBM, MNVO, RC, RAG, MHRF; Investigation: JCD, PSBM, MNVO; Methodology: JCD, PSBM, MNVO, RC, RAG, MHRF; Project administration: JCD; Resources: JCD, PSBM, MNVO, RC, RAG, MHRF; Supervision: JCD; Validation: JCD, PSBM, MNVO, RC, RAG, MHRF; Writing - original draft: JCD, PSBM, MNVO, RC, RAG, MHRF; Writing review \& editing: JCD, PSBM, MNVO, RC, RAG, MHRF.

Conflict of interest: The authors declare that there are no conflicts of interest.

Financing source: Celulose Nipo-Brasileira (Cenibra) (CNB4600003464).

\section{Literature Cited}

Andresen, L. C.; Carrillo, Y.; Macdonald, C. A.; CastañedaGómez, L.; Bode, S.; Rütting, T. Nitrogen dynamics after two years of elevated $\mathrm{CO} 2$ in phosphorus limited Eucalyptus woodland. Biogeochemistry, v. 150, n. 3, p. 297-312, 2020. https://doi.org/10.1007/s10533-020-00699-y.

Arafat, Y.; Tayyab, M.; Khan, M. U.; Chen, T.; Amjad, H.; Awais, S.; Lin, $S$. Long-term monoculture negatively regulates fungal community composition and abundance of tea orchards. Agronomy, v. 9, n. 8, p. 466, 2019. https://doi.org/10.3390/agronomy9080466.

Baumert, V. L.; Vasilyeva, N. A.; Vladimirov, A. A.; Meier, I. C.; Kögel-Knabner, I.; Mueller, C. W. Root exudates induce soil macroaggregation facilitated by fungi in subsoil. Frontiers in Environmental Science, v. 6, e140, 2018. https://doi.org/10.3389/ fenvs.2018.00140.

Braga, R. M.; Dourado, M. N.; Araújo, W. L. Microbial interactions: ecology in a molecular perspective. Brazilian Journal of Microbiology, v. 47, suppl. 1, p. 86-98, 2016. https://doi. org/10.1016/j.bjm.2016.10.005.

Castaño, C.; Dejene, T.; Mediavilla, O.; Geml, J.; Oria-De-Rueda, J. A.; Martín-Pinto, P. Changes in fungal diversity and composition along a chronosequence of Eucalyptus grandis plantations in Ethiopia. Fungal Ecology, v. 39, p. 328-335, 2019. https://doi. org/10.1016/j.funeco.2019.02.003.

Domeignoz-Horta, L. A.; Pold, G.; Liu, X. J. A.; Frey, S. D.; Melillo, J. M.; Deangelis, K. M. Microbial diversity drives carbon use efficiency in a model soil. Nature Communications, v. 11, n. 1, p. 1-10, 2020. https://doi.org/10.1111/1758-2229.12822.

Food and Agriculture Organization of the United Nations - FAO. Global data on forest plantations resources. http://www.fao.org/ docrep/004/Y2316E/y2316e0b.htm. 12 Oct. 2020.

Gong, X.; Liu, C.; Li, J.; Luo, Y.; Yang, Q.; Zhang, W.; Feng, B. Responses of rhizosphere soil properties, enzyme activities and microbial diversity to intercropping patterns on the Loess Plateau of China. Soil and Tillage Research, v. 195, e104355, 2019. https:// doi.org/10.1016/j.still.2019.104355.

Green, S. J.; Leigh, M. B.; Neufeld, J. D. Denaturing gradient gel electrophoresis (DGGE) for microbial community analysis. In: McGenity, T.J.; Timmis, K.N.; Nogales, B. (Eds.). Hydrocarbon and lipid microbiology protocols. Berlin: Springer, 2015. p.77-99. https://doi.org/10.1007/8623_2015_99.

He, T.; Wang, Q.; Wang, S.; Zhang, F. Nitrogen addition altered the effect of belowground $C$ allocation on soil respiration in a subtropical forest. Plos One, v. 11, n. 5, e0155881, 2016. https:// doi.org/10.1371/journal.pone.0155881.

lacumin, L.; Cecchini, F.; Vendrame, M.; Comi, G. Emulsion PCR (ePCR) as a Tool to Improve the Power of DGGE Analysis for Microbial Population Studies. Microorganisms, v. 8, n. 8, e1099, 2020. https://doi.org/10.3390/microorganisms8081099.

Kyaschenko, J.; Clemmensen, K. E.; Karltun, E.; Lindahl, B. D. Belowground organic matter accumulation along a boreal forest fertility gradient relates to guild interaction within fungal communities. Ecology Letters, v. 20, n. 12, p. 1546-1555, 2017. https://doi.org/10.1111/ele.12862. 
Lance, A. C.; Carrino-Kyker, S. R.; Burke, D. J.; Burns, J. H. Individual plant-soil feedback effects influence tree growth and rhizosphere fungal communities in a Temperate Forest Restoration Experiment. Frontiers in Ecology and Evolution, v. 7, e00500, 2020. https://doi.org/10.3389/fevo.2019.00500.

Li, L. J.; Zhu-Barker, X.; Ye, R.; Doane, T. A.; Horwath, W. R. Soil microbial biomass size and soil carbon influence the priming effect from carbon inputs depending on nitrogen availability. Soil Biology and Biochemistry, v. 119, p. 41-49, 2018. https://doi. org/10.1016/j.soilbio.2018.01.003.

Marupakula, S.; Mahmood, S.; Clemmensen, K. E.; Jacobson, S.; Högbom, L.; Finlay, R. D. Root associated fungi respond more strongly than rhizosphere soil fungi to $\mathrm{N}$ fertilization in a boreal forest. Science of The Total Environment, v.766, e142597, 2020. https://doi.org/10.1016/j.scitotenv.2020.142597.

May, L. A.; Smiley, B.; Schmidt, M. G. Comparative denaturing gradient gel electrophoresis analysis of fungal communities associated with whole plant corn silage. Canadian Journal of Microbiology, v. 47, n. 9, p. 829-841, 2001. https://doi.org/10.1139/w01-086.

Mommer, L.; Cotton, T. A.; Raaijmakers, J. M.; Termorshuizen, A. J.; Van Ruijven, J.; Hendriks, M.; Smit-Tiekstra, A. E. Lost in diversity: the interactions between soil-borne fungi, biodiversity and plant productivity. New Phytologist, v. 218, n. 2, p. 542-553, 2018. https://doi.org/10.1111/nph.15036.

Nübel, U.; Engelen, B.; Felske, A.; Snaidr, J.; Wieshuber, A.; Amann, R. I.; Backhaus, $H$. Sequence heterogeneities of genes encoding $16 \mathrm{~S}$ rRNAs in Paenibacillus polymyxa detected by temperature gradient gel electrophoresis. Journal of Bacteriology, v. 178, n. 19, p. 56365643, 1996. https://doi.org/10.1111/j.1574-6968.2010.02097.x.

Omotayo, O. P.; Babalola, O. O. Resident rhizosphere microbiome's ecological dynamics and conservation: Towards achieving the envisioned Sustainable Development Goals, a review. International Soil and Water Conservation Research, v.9, n.1, p.127-142, 2020. https://doi.org/10.1016/j.iswcr.2020.08.002.
Oros-Sichler, M.; Gomes, N. C.; Neuber, G.; Smalla, K. A new seminested PCR protocol to amplify large 18S rRNA gene fragments for PCR-DGGE analysis of soil fungal communities. Journal of Microbiological Methods, v. 65, n. 1, p. 63-75, 2006. https://doi. org/10.1016/j.mimet.2005.06.014.

Schloter, M.; Nannipieri, P.; Sørensen, S. J.; Van Elsas, J. D. Microbial indicators for soil quality. Biology and Fertility of Soils, v. 54, n. 1, p. 1-10, 2018. https://doi.org/10.1007/s00374-017-1248-3.

Shi, Y.; Dang, K.; Dong, Y.; Feng, M.; Wang, B.; Li, J.; Chu, H. Soil fungal community assembly processes under long-term fertilization. European Journal of Soil Science, v. 71, n. 4, p. 716726, 2020. https://doi.org/10.1111/ejss.12902.

Trivedi, P.; Leach, J. E.; Tringe, S. G.; Sa, T.; Singh, B. K. Plantmicrobiome interactions: from community assembly to plant health. Nature Reviews Microbiology, v.18, p. 607-621, 2020. https://doi.org/10.1038/s41579-020-0412-1.

Vainio, E. J.; Hantula, J. Direct analysis of wood-inhabiting fungi using denaturing gradient gel electrophoresis of amplified ribosomal DNA. Mycological Research, v. 104, n. 08, p. 927-936, 2000. https://doi.org/10.1017/S0953756200002471.

Wan, S.; Liu, Z.; Chen, Y.; Zhao, J.; Ying, Q.; Liu, J. Effects of lime application and understory removal on soil microbial communities in subtropical Eucalyptus L'Hér. plantations. Forests, v. 10, n. 4, e338, 2019. https://doi.org/10.3390/f10040338.

Zhang, Y.; Dong, S.; Gao, Q.; Ganjurjav, H.; Wang, X.; Geng, W. "Rare biosphere" plays important roles in regulating soil available nitrogen and plant biomass in alpine grassland ecosystems under climate changes. Agriculture, Ecosystems \& Environment, v. 279, p. 187-193, 2019. https://doi.org/10.1016/j.agee.2018.11.025.

Zhu, L.; Wang, X.; Chen, F.; Li, C.; Wu, L. Effects of the successive planting of Eucalyptus urophylla on soil bacterial and fungal community structure, diversity, microbial biomass, and enzyme activity. Land Degradation \& Development, v. 30, n. 6, p. 636-646, 2019. https://doi.org/10.1002/ldr.3249. 